\title{
PartyPolitics
}

\section{How effects on party unity vary across votes}

\author{
Christian Stecker \\ Ludwig-Maximilians-University Munich, Germany
}

\begin{abstract}
Our current knowledge of the causes of party unity rests heavily on the analysis of average unity scores of party groups from different countries. This study design invites two related problems: By aggregating unity scores we miss valuable variance at the level of disaggregated votes, and by comparing these aggregate scores across time and countries we might confound institutional effects with an unobserved case-specific selection bias of roll-call votes. In taking advantage of the laboratory-like conditions of the 16 sub-national parliaments of Germany and shifting the level of analysis to party unity in every single vote this article addresses both problems. Analysing 8607 unity scores, it is shown that the voting context is an important moderator of institutional effects on party unity. Specifically, it is shown that government status boosts party unity particularly within legislative important votes. Furthermore, the unity-boosting effect of slim majorities is only present for government parties and particularly strong when legislative consequential decisions are taken. Beyond that I also show that roll-call vote request, increasing ideological distances and norms of party loyalty increase party unity.
\end{abstract}

\section{Keywords}

Party unity, roll calls, selection bias

\section{Introduction}

Much of our current knowledge about the causes of party unity is reliant on cross-national studies using average unity scores of parties as unit of analysis. ${ }^{1}$ In a typical study design, unity scores (e.g. Rice, 1928) from different countries are pooled for party groups in a period in which explanatory variables remain stable - usually a parliamentary term (e.g. Carey, 2007; Depauw and Martin, 2008; Hix et al., 2005; Sieberer, 2006b). The variance in these scores is then explained by theoretically interesting variables at the system level (e.g. regime type or personal vote incentives), the parliamentary level (e.g. size of the governmental majority) and the party level (e.g. government status, ideological distances to other party groups).

This dominant study design invites two partly related problems. First, the aggregation of unity scores neglects valuable variance of party unity at the level of individual legislative votes. Aggregate scores, to name one important example, pool the unity of parties on different types of motions, such as non-binding resolutions, budget laws, ordinary laws and amendments. Yet, there are good reasons for expecting that institutional effects on party unity do not work equally across different types of motions (e.g. Coman, 2012; Crespin et al., 2011; Høyland, 2010). Party leaders will be more willing to use carrots and sticks in important votes than in votes on non-legislative resolutions. By the same token, individual MPs will value party unity differently across different motions. In other words, institutional and situational explanations of party unity should matter more when party unity matters. Furthermore, requesting a roll-call vote (RCV) most likely boosts the observable unity of the respective party group - either because it is used to monitor and discipline members (Carrubba et al., 2008) or it is requested to signal positions on which the party is in perfect agreement (and other parties divided) (Stecker, 2010). Yet, this effect is best detectable at the level of individual votes.

Second, as the selection of RCVs in each parliament is governed by different rules on agenda formation (Zubek, 2011), on RCV requests (Hug, 2010) and by parties' RCV

Paper submitted I8 August 2013; accepted for publication II December 2012

\section{Corresponding author:}

Christian Stecker, Ludwig-Maximilians-Universität, Geschwister-SchollInstitut für Politikwissenschaften, Oettingenstraße 67, 80538 München, Germany.

Email: chr.stecker@gmail.com 
requesting strategies (Carrubba et al., 2006; Saalfeld, 1995a; Stecker, 2010), (aggregate) unity scores from different countries also carry different meanings. Inferences based on these (aggregate) scores may hence be distorted by the varying country-specific selection bias of RCV samples (Cheibub, 2007: 134).

Of course, the problems of aggregation and selection bias are not intrinsic to cross-national study designs (nor is their solution intrinsic to sub-national study designs). Intimate knowledge of cameral rules and practices - as it is currently collected (Hug, 2010) - as well as qualitative information on each vote would allow students of party unity to model the country-specific selection of votes (Crespin et al., 2011) and to take into account the specific context of each vote. Yet, collecting additional information on some thousand roll calls from parliaments from different continents with different languages and varying accessibility poses a resource-demanding hurdle that has not yet been taken. ${ }^{2}$

This article, therefore, takes an alternative route to address both problems. In analysing party unity during 46 electoral terms of the 16 sub-national parliaments of Germany (Landtage), this study profits from methodological and practical advantages: Within these subnational parliaments, similar cameral rules on agenda formation and $\mathrm{RCV}$ requests, as well as similar party compositions, minimize the risk of selection bias. Furthermore, vote-specific information such as about the requesting party and about the type of motion are comparatively easy to collect and allow me to shift the level of analysis down to party unity on each vote. At the same time, the Landtage provide for a promising experimental variance to test institutional effects on party unity. Based on this almost laboratory-like environment, this article adds different insights to our current knowledge about the causes of party unity in parliamentary systems.

My overarching finding is that the type of motion, i.e. the difference between legislative and non-legislative votes, is an important moderator of institutional and situational effects on party unity: Specifically, I find that government status increases party unity on average but that this effect is particularly strong in legislative (e.g. amendments) as compared to non-legislative (e.g. resolutions) votes. Furthermore, an increase in the size of the government's majority only decreases government party unity if the roll is called on non-legislative votes. The data also reveal a strong increase in the voting unity of the party that requested the recorded vote. Beyond that it is also shown that higher ideological distances between government and opposition increase unity. Due to the unique overpopulation of Eastern German Landtage with party-sceptic MPs after reunification, I can also sketch how party loyalty complements the well-known institutional pathways to party unity (cf. Andeweg and Thomassen, 2011).

The remainder of this article is structured as follows. In the next section, I elaborate on the problems of using aggregate unity scores and case-specific selection bias and show how my study design avoids both difficulties. I then discuss selected hypotheses about the causes of party unity with explicit consideration of the voting context of different votes. After presentation of the dataset and measurement decisions I turn to the empirical models used to test the hypotheses. In conclusion, I deal with the implications of my results for the study of party unity.

\section{Little control of selection bias and too much aggregation}

Recent studies on legislative voting have identified two, partly related problems of research on party unity: ${ }^{3}$ the widespread use of pooled unity scores and a countryspecific selection bias of RCV. First, by aggregating unity scores we miss valuable explanatory and control variables that exist at the level of each vote. Most problematic, aggregate scores pool the unity of parties across different types of motions such as resolutions and bills. Yet, the type of motion may be directly related to the level of party unity (cf. Crespin et al., 2011: 4) and/or may also moderate institutional effects on unity. A closer look at the Swiss lower chamber illustrates this point: Here, Hug (2010: 5) compares party unity between different motions. He finds that party unity is highest on final passage and emergency measures and argues that this higher unity in final passage votes could be caused by two factors: intra-party conflict might have been resolved before the vote and/or whips are more ready to impose party discipline to achieve unity on such important measures. Particularly the latter cause constitutes an important moderator of institutional effects on party unity. To a high degree the type of motion correlates with the importance of the voting matter. Final passage votes and amendments are legislative consequential, whereas votes on resolutions do not have direct policy implications. As whips can be expected to care more about unity in legislative consequential votes where the party's reputation as 'policy-making agent' (Ozbudun, 1970: 303) is at stake, they should concentrate the usage of carrots and sticks on these votes. In fact, Coman (2012) finds that Romanian MPs are allowed more flexibility on all votes other than on final passage. Similarly, Høyland (2010) demonstrates that in the European parliament the influence of parties on their MPs voting behaviour is vote-specific. Accordingly, the effect and explanatory power of institutional variables embodying carrots and sticks should depend on the type of motion under consideration. In the extremes, the type of motion might even turn around the direction of effects. Imagine that the government encourages its MPs to vote on resolutions according to their constituencies' preferences in order to compensate for the often painful unity it has to enforce on legislative consequential votes. Government status could then increase unity in important votes, but decrease it if symbolic matters are on the table. 
Obviously, aggregate scores may remain silent on this interesting individual-vote-level effect as both directions may cancel each other out. Ignoring this and other withinsample variations by aggregating unity scores may therefore lead to different inferential errors. ${ }^{4}$

A second problem arises if (pooled) unity scores are compared across cases, e.g. in order to gain experimental variance for testing institutional effects on party unity (Carey, 2007; Sieberer, 2006b). As has been shown in different studies, the selection of RCV varies both longitudinally (Crespin et al., 2011) and cross-sectionally (Hug, 2010). The resulting sample (or population) of RCVs may thereby be biased along different dimensions and in different directions. In as much as these dimensions are also systematically related to the level of party unity, any uncontrolled selection bias poses a serious obstacle to inferences about institutional effects. Three sources of selection bias are particularly relevant in this regard: rules on agenda formation, rules on $\mathrm{RCV}$ requests and strategic behaviour of RCV requesting parties: First, the distribution of agenda-setting powers influences which specific intra and inter-party preference distributions may enter the voting stage. As Cox and McCubbins (2005) have most prominently shown, the majority party in the U.S. Congress can use its gatekeeping power to keep proposals off the floor that could split the majority. Hence, the varying existence and institutionalization of agenda control (e.g. Zubek, 2011) determines to what extent intra-party heterogeneity (within the majority) could lead to lower voting unity (Blumenau, 2012). ${ }^{5}$

Second, rules on RCV request influence the likelihood with which different kinds of motions enter the roll-call sample. ${ }^{6}$ In some parliaments, for example, all votes are by roll call (e.g. U.S. Congress), whereas in others RCVs are only a subsample of all votes. In the latter group, there are parliaments in which votes on the final passage of legislation have to be by roll call (e.g. Italy (De Georgi and Marangoni, 2011)), whereas in others this only occurs if requested by a party group (e.g. Germany (Saalfeld, 1995b)). Procedural decisions may be open to roll calls in some parliaments, whereas they must not be taken by RCV in others. As has been discussed above, any bias towards specific types of motion ${ }^{7}$ potentially influences the (aggregate) level of party unity. ${ }^{8}$

A third source of selection bias is driven by parties' RCV-requesting strategies. In many parliaments RCV samples are created by parties' deliberate requests for such votes. Accordingly, parties' goals behind these requests (Ainsley and Maxwell, 2012; Saalfeld, 1995a) influence the nature of the sample. Depending on whether parties and MPs try to signal own policy positions, control and discipline MPs, or aim at embarrassing other parties, the sample may be skewed towards different issues and legislative activities (Crisp and Driscoll, 2012). ${ }^{9}$ In the European parliament, for example, parties predominantly call for RCVs on rather unimportant issues and in policy areas alongside the left-right dimension. European parties want to look united and in these areas they can rely on relatively costfree cohesion-induced unity (Carrubba et al., 2006; Thiem, 2006, 2009: ch. 7), which is not guaranteed in the case of important votes and in other policy areas.

In a nutshell, if we do not control for these various dimensions of selection bias, our inferences about institutional effects are vulnerable to omitted variable bias, ${ }^{10}$ as we might erroneously relate party unity in a country to its institutional setup, although it could also be driven by the selection process of roll calls. To be fair, comparative scholars spare no effort to control for different sources of selection bias in their empirical analyses, for example by weighting votes by the closeness of their results (Carey, 2007: 97). Yet, an optimal remedy could only be achieved on the basis of a detailed theoretical and empirical understanding of each country's RCV sample. Part of that understanding lies in intimate knowledge of the respective passages in standing rules and about the behavioural practices as currently developed by Hug's (2009) project. Another part lies in collecting additional data on each roll call, most importantly about the importance of the voting matter. With this information a selection of more homogeneous samples of recorded votes would provide a better testing ground. Yet, in light of the already painstaking effort to collect comparative data on unity, date and threshold for approval for each vote (Carey, 2007: 98), the second strategy could only be subject to a future collective research endeavour.

This article advances research on party unity by studying the phenomenon in an environment that makes addressing both problems easier. In analysing party unity in the 16 sub-national parliaments of Germany I take advantage of their almost identical regulation of agenda formation, RCVs and similar party compositions that minimize the risk of selection bias (Snyder, 2001). Furthermore, I disaggregate unity scores and use the explanatory value of the type of motion and of the RCV-requesting party. In the following I discuss selected effects on party unity with explicit regard for vote-specific factors.

\section{Cohesion, discipline and loyalty - pathways to party unity}

In theorizing about the causes of party unity I build on the established analytical distinction between party cohesion, party discipline and party unity (Hazan, 2006). Whereas party unity denotes the observable behaviour, cohesion and discipline can be understood as two different pathways to unity (Andeweg and Thomassen, 2011: 3f.). Thereby, cohesion denotes the homogeneity of preferences within a party (and heterogeneity between parties). Perfect unity comes by default if all MPs share identical preferences on the matter of a given vote (Krehbiel, 1999). Party 'discipline starts where cohesion falters' (Hazan, 2006: 3). 
If MPs are in disagreement they might still toe the party line if they want to avoid sanctions or profit from positive incentives that are at the disposal of the party leadership.

From a rationalist perspective, voting in parliaments is often conceptualized as a game between individual MPs, the party leadership and other competing principals of MPs (Carey, 2007), such as district voters or interest groups. The voting decisions of individual MPs are influenced by the goals they pursue - most importantly to get (re)nominated and (re)elected, to influence public policy and to climb up the career ladder (Müller and Strøm, 1999). The institutional context in which MPs operate determines how these goals can be achieved. Most importantly it determines how strongly the behaviour of individual MPs is driven towards party unity (Cox and McCubbins, 1993). In an ideal case, individual MPs can only achieve their goals by subordinating to the collective interests of the party pursued by the party leadership (Patzelt, 2006: 105). If, however, MPs must also respond to competing demands, such as from primary and district voters or interest groups, their behaviour is pulled away from always being in line with the party. The question of how these competing pressures finally determine the level of party unity in a political system has usually been answered by focusing on the relative power of party leaders and other principals of MPs (Carey, 2007). Adding vote-specific factors to the picture - as I will do in the following - allows us further to understand how and why incentives for party unity vary across votes.

A central question in the study of party unity is the effect of government status in parliamentary democracies. Theoretically speaking, government participation can be expected to have conflicting effects on party unity. On the one hand, when in government party leaders command more carrots and sticks to induce unity, most importantly by the threat of confidence votes (e.g. Diermeier and Feddersen, 1998; but see Curini and Zucchini, 2012). However, in contrast to the opposition, government parties are forced to vote upon unpopular policies. Matters may be worse under the frequent situation of coalition government when individual parties need to agree on painful compromises (Delius et al., 2013). Hence, government status influences party unity via different pathways into different directions. It increases the chances for discipline-induced unity while decreasing it via lowering the cohesion. Empirical accounts (using aggregate scores) of the question provided mixed results: Whereas Carey (2007: 103) finds government status (in parliamentary systems) to boost unity, Sieberer (2006b: 167) and (although not significant) Depauw and Martin (2008: 111) present evidence for the opposite effect. The exact reason for these contradictory findings (and in how far they are linked to aggregation and selection bias within the studies' samples) remains unclear. Nevertheless, here I argue that we can provide an empirically more accurate and substantively more important answer to the effect of government status if we explicitly consider the type of motion as a contextual variable. Government unity most likely varies between important and unimportant votes, as incentives for unity vary accordingly. As suggested above, rational whips should concentrate the usage of carrots and sticks on voting measures where the government's ability as 'policymaking agent' (Ozbudun, 1970) is at stake. This unity in important votes does not have to be enforced by blunt discipline. On the one hand, unity may also be achieved via the route of increasing cohesion by accommodating backbenchers' policy positions. On the other hand, Coman (2012) has shown for Romania that the government - as compensation for unity in important votes - may allow and even encourage party-independent activities in less damaging areas such as questions to the government or less important votes. ${ }^{11}$ Consequently, government unity should be higher in legislative important votes. Instead of focusing on aggregate government unity the difference between unity in legislative and non-legislative votes is also more relevant from a normative point of view. As a prerequisite for responsible party government, party unity is obviously more relevant in legislative consequential decisions.

Hypothesis 1: Government unity is higher in legislative compared to non-legislative votes.

As follows from the logic of parliamentary government, the size of governmental majorities is an important factor for party unity. It is first and foremost the government that needs sufficient unity to win legislative votes (Cox and McCubbins, 2005: 218). The level of sufficient unity is determined by the number of seats the government enjoys above the threshold of approval. The fewer seats it controls, the lesser dissent can be tolerated (Bowler et al., 1999: 14). Oversized majorities, however, reduce the cost of dissent. Furthermore, with increasing size of their backbench government party leaders have fewer rewards for loyal behaviour at their disposal (Benedetto and Hix, 2007). To a lesser extent this logic also applies to the opposition. If it commits to a united front against the government, opposition parties may force the government to rely entirely on its own unity and might thereby even extract some policy concessions (Dewan and Spirling, 2011).

Hypothesis 2: Shrinking governmental majorities increase party unity.

Hypothesis 2a: This effect is stronger for government parties than for opposition parties.

Similar to government status, this effect will likely be moderated by the type of motion. Any additional dissenting vote - even if affordable in terms of the government's vote surplus - will be more damaging to the government 
parties' reputation if legislative consequential decisions are taken.

Hypothesis 3: The government-unity decreasing effect of growing majority sizes should be stronger for nonlegislative votes.

As discussed, parties pursue different goals with RCV requests: signalling own positions, disciplining backbenchers or embarrassing other parties by revealing their unpopular positions and disunity (Saalfeld, 1995a). The literature disagrees about the relative importance of each goal. Some scholars (Carey, 2009; Stecker, 2010) reject the idea that recorded votes are an attractive instrument for monitoring voting behaviour of backbenchers, whereas others deem this possible (Carrubba et al., 2008). Regardless of the specific goal pursued, any RCV request should lead to a similar effect: an increase in the observable degree of unity of the requesting party.

Hypothesis 4: RCV requests increase the unity of the respective party.

The distribution of political preferences is a central factor for unity, as denoted in the term 'party cohesion'. High intra-party homogeneity and high inter-party heterogeneity lead to unity even in a discipline-free world (Krehbiel, 1999; Owens, 2006: 13). In cases of two-party parliaments, party unity should accordingly increase with ideological distance. In multiparty parliaments the situation is more complex. Obviously, increasing distances between government parties would rather be a liability for their unity. As legislative voting in parliamentary democracies is often an implicit comparison between a preferred government policy and oppositional alternatives, the political distance between government and opposition should be an appropriate predictor for party unity. Accordingly:

Hypothesis 5: Increasing distance between government and opposition increases party unity.

I have argued that one problem of using average unity scores lies in the fact that these averages combine unity scores for different types of motion. However, different motions will not only moderate specific effects on party unity bus also the explanatory power of empirical models. More, precisely, empirical models about institutional effects should account for a higher share of the variance in unity scores if we focus on legislative consequential votes.

Hypothesis 6: The explanatory power of empirical models increases in legislative consequential votes.

Andeweg and Thomassen (2011: 3) criticize current research for focusing too strongly on only two pathways to party unity: cohesion and discipline. Yet members may also toe the party line out of a logic of appropriateness which can be summarized in 'the norm that an MP should not publicly deviate from his or her party' (Andeweg and Thomassen, 2011: 10; Kam, 2009). As their survey indicates that loyalty supersedes sanctions in securing unity, I devise an approximating test of this factor.

Hypothesis 7: Party unity increases the stronger MPs subscribe to norm of party loyalty.

\section{Study design}

The empirical test of these hypotheses draws on original data I collected on roll-call voting in 46 terms of all 16 sub-national parliaments in Germany (Landtage) between 1990 and $2011 .^{12}$ The state parliaments offer an environment in which the risk of case-specific selection bias is minimized. First, with regard to agenda-formation and RCV requests, all 16 parliaments stipulate very similar rules. Similar to the German Bundestag (cf. Sieberer, 2006a), the agenda is set by all parties consensually and no effective negative agenda control is possible. In all state parliaments signal voting is the standard operating procedure. Yet, recorded votes may be held at the request of a party group. ${ }^{13}$ Note that procedural votes such as on committee referral or adjournments must not be by roll call. Only resolutions, amendments, bills and constitutional changes are open to roll calls. Furthermore, the party composition of state parliaments is very similar. The 'usual inhabitants' of the state parliaments are the Social Democrats (SPD), the Christian Democrats (CDU, CSU in Bavaria), the Greens and Liberal Democrats (FDP) and the Left (formerly PDS, concentrating in the East) (Mielke and Reutter, 2004; Jun et al., 2008). To a great extent, the party systems in the states thereby mirror the national party system. Occasionally, radical right-wing parties and niche parties gained representation in the state parliaments. Yet, information about the mover of motions for all votes allows me to control their influence on the voting agenda. Beyond the high control of potentially disturbing factors, the state parliaments offer a promising variance in different government party constellations, governmental majorities and ideological distances.

The unit of analysis in this study is the unity of a party group in a given vote. In calculating unity scores, I use the index of agreement (cf. Hix et al., 2005). This index is calculated as follows, whereby ' $\mathrm{Y}$ ', ' $\mathrm{N}$ ' and 'A' represent Yesvotes, No-votes and abstentions, respectively:

$$
A I_{i}=\frac{\max \left\{Y_{i}, N_{i}, A_{i}\right\}-\frac{1}{2}\left[\left(Y_{i}+N_{i}+A_{i}\right)-\max \left\{Y_{i}, N_{i}, A_{i}\right\}\right]}{\left(Y_{i}+N_{i}+A_{i}\right)}
$$

The index ranges between 1 (when all party members vote together) and 0 (when all members are equally distributed across the three categories). I had to exclude non-votes because it was impossible to interpret their substantive meaning with regard to party unity. ${ }^{14}$ Using alternative 
measures, such as the classic Rice index and the correction for small group bias, introduced by Desposato (2005), reduces the variance in unity scores, but leaves substantive results unchanged.

In total, I analyse 8607 unity scores from all 2402 recorded votes held during 46 electoral terms. The analysis is restricted to the five main parties of the party systems in the German states (see above). I also dropped votes from the analysis that were unanimous across all these five parties.

As can be seen from the table, the number of recorded votes varies considerably across parliaments. Especially Eastern parliaments and Bavaria and Baden-Württemberg provide a higher number, which is partly a function of voting technology and the presence of niche parties (Stecker, 2010). As I use different information at the level of each vote, such as for the importance of motions and RCVrequesting parties, the unequal number of votes should not introduce relevant bias.

Independent variables were coded as follows: The size of the governmental majority is coded as the absolute number of seats governing parties control above the absolute majority requirement. It takes the value of zero if the government controls 50 percent plus one seat. ${ }^{15}$ The degree of ideological divergence between government and opposition is calculated by using data on party positions on a left-right scale provided by Bräuninger and Debus (2012; Müller, 2009). Applying the wordscore method on electoral manifestos, they calculated positions for all relevant parties and each term. I follow established practice and determine the government's and opposition's position by the average of the positions of each coalition or opposition party weighted by its seat-share (cf. Martin and Vanberg, 2004). It is desirable to complement this measure of inter-party heterogeneity with information on intra-party homogeneity. Unfortunately, at this time no such measures exist (Pappi and Seher, 2009). Government status and RCV request are coded straightforwardly as dummies.

To test how far institutional effects on party unity are moderated by the importance of the motion that is voted upon, I discern dichotomously between legislative and non-legislative votes (cf. Green-Pedersen, 2010). I code votes as legislative if their results exert direct policy implications such as the adoption or rejection of bills and amendments. Different types of resolutions are coded as non-legislative votes. Although these votes might be of high symbolic value, they do not change a single letter in the statute book. In practice, the importance of votes will of course vary within these categories, such as between budget bills and technical bills. Furthermore, some final passage votes might be foregone conclusions based on votes on previous amendments. Accounting for such differences, however, requires a demanding data collection which is unfortunately beyond this study. Nevertheless, a dummy coding suffices to capture the average moderating effect of the type of motion.
To measure the degree of party loyalty, I take advantage of the unique historical situation that existed after reunification in Germany: Although by ways of institutional transfer from the West almost identical parliamentary institutions had been erected in Eastern Germany, the political personnel differed considerably between East and West in the first years after 1990. Deeply impressed by their experiences under communist one-party-rule and being politically socialized in the reform movement, many Eastern German MPs harboured a high distrust of parties and party-based decision-making (Davidson-Schmich, 2006: 88; Patzelt, 1997; Yoder, 1999). Only after two terms did eastern MPs (mostly due to high turnover) adapt to the 'Western' standards of party loyalty. I, therefore, introduce a dummy variable for all Eastern German parliaments in their first two terms after reunification.

\section{Empirical analysis}

The distribution of the index of agreement shows that perfect unity is the rule rather than the exception in the German state parliaments. In 77.5 percent of a total of 8,607 unity scores perfect unity is achieved. The average index of agreement lies at 95.2. Dissent rarely leads to relevant policy implications as government party groups almost always vote sufficiently united to win votes. Only 28 votes are lost by the government due to disunity. Note, however, that these losses mostly occur due to insufficient coalition unity, where different government parties vote - highly united - against each other.

Before turning to the multivariate test, some challenges in the data structure need to be discussed. First, the hypotheses work on three different levels: government majorities and political distances on parliamentary level, government status on party group-level and finally RCV request on the level of each vote. This nested structure seems to beg for a multi-level-model specification. Yet, the non-randomly selected, small number of only 16 different states and the not consistently hierarchical structure of the data precludes this possibility (Braun et al., 2010: 20-22; Hox, 2002; Snijders, 2003: 676). ${ }^{16}$ Second, bounded between 0 and 1 the index of agreement is a limited dependent variable which could be analysed adequately with a fractional response model (Long and Freese, 2006). For a better interpretation of the results and to enable comparability with existing works (Carey, 2007; Depauw and Martin, 2008), I nevertheless present the results with ordinary least squares regression. In order to control for the interdependence of observations, standard errors are clustered at the level of each vote.

Table 1 presents the results of five regression models. Model 1 contains estimates from the full dataset of all 7,176 unity scores with non-missing values on explanatory variables. As can be seen, government status increases unity by almost 2.9 points in the index of agreement. 
Table I. Effects on party unity and voting context (OLS regression).

\begin{tabular}{|c|c|c|c|c|c|}
\hline & Model I & Model 2 & $\begin{array}{c}\text { Model } 3 \\
\text { Fixed effects }\end{array}$ & $\begin{array}{c}\text { Model } 4 \\
\text { Non-legislative }\end{array}$ & $\begin{array}{l}\text { Model } 5 \\
\text { legislative }\end{array}$ \\
\hline Government status & $2.852 * * *(8.08)$ & $3.621^{* * * *}(7.49)$ & $3.525 * * *(7.38)$ & $2.948 * * *(4.55)$ & $4.323 * * *(5.92)$ \\
\hline Majority size & $-0.007(-0.62)$ & $0.023(\mathrm{I} .52)$ & $0.009(0.39)$ & 0.0249 (I.29) & $0.020(0.80)$ \\
\hline $\mathrm{RCV}$ request & $4.666 * * *(13.4 I)$ & $4.604 * * *(13.23)$ & $4.572 * * *(12.86)$ & $4.265 * * *(10.17)$ & $5.161 * * *(9.01)$ \\
\hline Political distance & $0.72 I^{* * * *}(4.34)$ & $0.718^{* * *}(4.32)$ & $0.44 I^{*}(2.02)$ & $0.483(1.86)$ & $0.914 * * *(4.35)$ \\
\hline Loyalty (East Germany) & $-5.145^{* * *}(-11.68)$ & -5.131 *** $(-11.62)$ & $-4.454 * * *(-7.86)$ & $-3.973 * * *(-6.05)$ & $-5.776 * * *(-10.13)$ \\
\hline Government* majority & - & $-0.067 * *(-2.84)$ & $-0.062 * *(-2.67)$ & $-0.103 * * *(-3.35)$ & $-0.013(-0.37)$ \\
\hline State dummies & - & - & not shown & - & - \\
\hline Constant & $86.82 * * *(46.25)$ & $86.53 * * *(46.09)$ & $88.96 * * *(38.67)$ & $89.34 * * *(30.88)$ & $83.92 * * *(35.22)$ \\
\hline$N$ & 7176 & 7176 & 7176 & 3428 & 3574 \\
\hline $\operatorname{adj} . R^{2}$ & 0.056 & 0.057 & 0.062 & 0.040 & 0.073 \\
\hline
\end{tabular}

Notes: $t$ statistics in parentheses; $*_{p}<0.05,{ }^{* *} p<0.01$, $*_{* *} p<0.00 \mathrm{I}$. Unit of analysis is party unity of a parliamentary party group on a vote measured by the index of agreement ranging between 0 and 100 .

Increasing political distances between government and opposition also significantly increase party unity. Each point increase in the political distance between government and opposition increases average party unity by 0.7 points. The distance varies empirically between 7.4 and 14.5. Interestingly, the strongest boost in unity is caused by RCV request. The party group that requested the roll-call profits by more than 4.6 points in unity. Capturing low party loyalty, the dummy for the first two terms in Eastern Germany after reunification also exhibits a strong and significant effect. The model suggests that with growing majority size all party groups tolerate more dissent, but this effect is not significant. I hypothesized that a unity-boosting effect of slim majorities should be particularly strong within the government, as it is foremost the government that needs unity to win legislative votes. Including an interaction term of government status and majority size in model 2 allows me to test this expectation. It emerges that majority size matters exclusively for the government parties' unity: the average marginal effect of majority size on government unity is -0.044 (standard error: 0.018 ) and statistically significant at the 5 percent level. As the coefficient for majority size now captures the conditional effect for opposition parties only (cf. Brambor et al., 2006), we see that seatshares obviously do not play a role in opposition MPs' voting calculus. Before examining this interaction effect in more detail, let me turn to the other models.

In order to check the robustness of these effects against unmodelled case-specific influences, I introduce dummies for each state except one in model 3. It is shown that all substantive effects remain almost unchanged..$^{17}$ Note that all effects are also robust against dropping individual states from the sample. I further suggested that the importance of motions moderates the effect of government status and majority size on party unity. This hypothesis is tested in the next two models, where the sample of all votes is split into votes held on non-legislative (Model 4) and on legislative votes (Model 5). A visual presentation of the effects differentiated into non-legislative and legislative votes, as well as the respective confidence intervals, is given in the coefficient plot in Figure 1.

The results strongly support the idea that different types of motions constitute a different voting context. First the explanatory power of the empirical model differs by an absolutely small but relatively high amount of 3.3 percent in explained variance. ${ }^{18}$ In other words, institutional and situational factors of party unity matter more when party unity matters. Second, the type of motion also moderates institutional effects on party unity. This is clearly shown by the effect of government status, majority size and their interaction on party unity. A graphical illustration of this moderation in Figure 2 presents the predicted unity score over the range of majority size both for government and opposition parties. This is done for non-legislative votes in the upper plot and legislative consequential votes in the lower plot. The plots clearly demonstrate that the effect of majority size on party unity is contingent on government status and moderated by the importance of the motion. Under non-legislative votes, every additional seat the government controls above the threshold of approval lowers the pressure for party unity within the government ranks. More precisely, the average marginal effect of majority size on government parties in non-legislative votes is -0.07 (significant at 1 percent level, standard error: 0.024). This effect is absent in opposition parties. With legislative consequential votes on the table, the reductive effect of majority size also vanishes in government parties. Hence, with regard to resolutions, government party leaders seem to tolerate dissent within the limits set by their majority surplus. In votes on bills and amendments, however, MPs are kept on a shorter leash regardless of majority size. Note that 80 percent of all votes are held under government majorities ranging between 0 and 17 seats above the absolute majority requirement and that the marginal effect of government status on party unity is significant within this interval. 


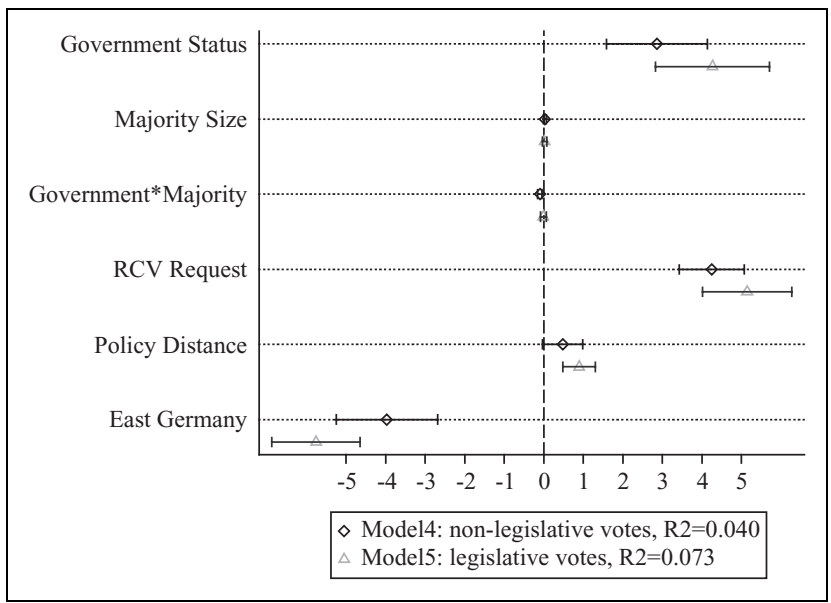

Figure I. Coefficient plot of effects on party unity in legislative and non-legislative votes (model 4 and model 5).

Notes: Squares and triangles represent the value of the coefficient. Capped spikes represent the range of the confidence interval.

Notes: Solid lines represent the predicted values of party unity for government and opposition parties for different values of governmental majorities (ranging between 0 and 38) based on the results from Model 4 in Table 1. Dashed lines represent the 95 percent confidence intervals.

\section{Conclusion}

In this article, I have addressed two major problems of the dominant approach to the study of party unity by using average unity scores of party groups from different countries. I argued in line with others that aggregation of unity scores neglects valuable variance that exists at the level of disaggregated legislative votes (Coman, 2012) and that inferences from the comparison of (aggregated) scores across countries are vulnerable to country-specific selection biases (Carrubba et al., 2006; Hug, 2010). As they offer a remedy to both problems, I studied party unity in the 16 sub-national parliaments of Germany. In analysing party unity with explicit consideration of the voting context a robust and insightful empirical test of different effects on party unity, specifically government status, majority size, RCV request, policy distances and party loyalty could be devised. As a genuinely new contribution I have shown that the importance of the motion voted upon is an important moderator of effects and explanatory power of empirical models of party unity. Within legislative consequential votes such as amendments or bills, institutional and situational factors account for a higher share of variance than in votes on non-legislative votes such as resolutions. Furthermore, the (unity-boosting) effect of government status and the (government unity-decreasing) effect of majority size are also conditioned by the type of motion.

What implications can be drawn from these findings for future research on party unity? First, the proven moderating

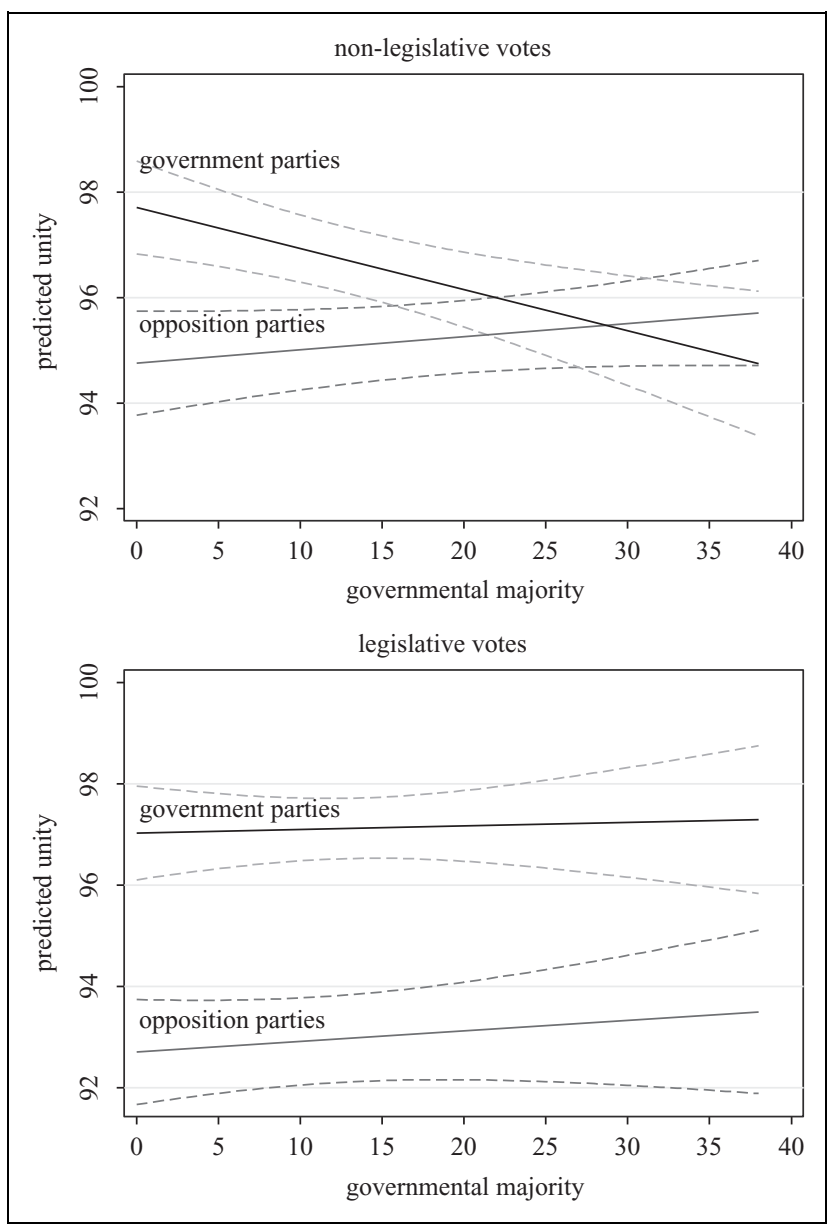

Figure 2. Effect of majority size on party unity conditioned by government status depending on legislative importance of a vote. Notes: Dashed lines represent the 95 percent confidence intervals.

effect of the importance of motions suggests that controlling for the voting context is a promising feature for any study on party unity. Instead of throwing together all sorts of votes into pooled unity scores, splitting the sample into more homogeneous sub-groups should increase robustness, explanatory power and substantive importance of our models. This desideratum applies equally to parliaments where all or only some votes are taken by roll call.

Second, the strong effect of RCV request on unity scores reminds us that we need to better understand the strategic calculus of parties behind their demand for visible votes if we want to study party unity with the vote sample they intentionally create. Whereas this question has already been studied in detail for the European Parliament (Carrubba et al., 2006) and many presidential democracies (Crisp and Driscoll, 2012), our knowledge of parliamentary democracies is still dim (Bräuninger et al., 2013; Stecker, 2009, 2010).

My paper illustrates that studying sub-national parliaments is a fruitful complement to the many laudable cross-national studies that have contributed to the field 
(Carey, 2007; Depauw and Martin, 2008; Sieberer, 2006b). Sub-national parliaments offer similar institutional environments that minimize the selection bias of roll-call samples and pose lower hurdles in data accessibility. Yet, this study design is of course not without limitations. Particularly for addressing the 'big' questions about the causes of party unity - such as about the effect of presidentialism and parliamentarism or electoral incentives - we rarely find the necessary institutional variance at the sub-national level. Hence, we are well advised to further improve cross-national studies of party unity. In light of the demanding data collection, this would have to be a collective research endeavour of the kind of which the study of party manifestos (Klingemann, 2006) or electoral behaviour (Dalton and Anderson, 2011) has largely profited. Such studies could provide a better understanding of a phenomenon that is - as a precondition of responsible party government (Hobolt et al., 2012) - central to democratic theory.

\section{Appendix I: Descriptive statistics}

\begin{tabular}{|c|c|c|c|c|c|c|}
\hline State & $\begin{array}{l}\text { Term } \\
\text { begin }\end{array}$ & $\begin{array}{l}\text { Term } \\
\text { end }\end{array}$ & $\begin{array}{l}\text { Majority } \\
\text { size }\end{array}$ & $\begin{array}{l}\text { Political } \\
\text { distance }\end{array}$ & $\begin{array}{l}\text { No. of } \\
\text { RCVs }\end{array}$ & $\begin{array}{c}\text { Mean Index of } \\
\text { Agreement }\end{array}$ \\
\hline Baden-Württemberg & $06 / 1992$ & $02 / 1996$ & 36 & 11.07 & 54 & 0.96 \\
\hline Baden-Württemberg & $06 / 1996$ & $02 / 2001$ & 5 & 12.23 & 77 & 0.99 \\
\hline Baden-Württemberg & $06 / 2001$ & $05 / 2006$ & 8 & 11.91 & 57 & 0.99 \\
\hline Baden-Württemberg & $06 / 2006$ & $04 / 2011$ & 14 & 12.36 & 17 & 0.98 \\
\hline Bavaria & $10 / 1994$ & $07 / 1998$ & 17 & $\mathrm{II} .55$ & 139 & 0.96 \\
\hline Bavaria & $09 / 1998$ & $07 / 2003$ & 20 & 10.82 & 169 & 0.98 \\
\hline Bavaria & $10 / 2003$ & $07 / 2008$ & 33 & 12.08 & 247 & 0.98 \\
\hline Berlin & $11 / 1995$ & $10 / 1999$ & 38 & 10.42 & 42 & 0.92 \\
\hline Berlin & $12 / 1999$ & $01 / 2002$ & 33 & || $.8 \mid$ & 14 & 0.97 \\
\hline Berlin & $01 / 2002$ & $08 / 2006$ & 6 & 8.70 & 36 & 0.94 \\
\hline Berlin & $10 / 2006$ & $09 / 2011$ & I & 8.48 & 23 & 0.99 \\
\hline Brandenburg & $10 / 1990$ & $06 / 1994$ & -3 & 10.04 & 94 & 0.89 \\
\hline Brandenburg & $10 / 1994$ & $08 / 1999$ & 7 & 9.84 & 64 & 0.93 \\
\hline Brandenburg & $09 / 1999$ & $08 / 2004$ & 17 & 10.22 & 125 & 0.97 \\
\hline Brandenburg & $10 / 2004$ & $08 / 2009$ & 8 & 10.65 & 50 & 0.99 \\
\hline Bremen & $07 / 1995$ & $05 / 1999$ & 23 & 10.88 & 6 & 0.96 \\
\hline Bremen & $07 / 1999$ & $05 / 2003$ & 38 & 10.67 & 3 & 0.96 \\
\hline Bremen & $07 / 2003$ & $04 / 2007$ & 27 & 10.54 & 2 & 1.00 \\
\hline Hamburg & $10 / 200 \mid$ & $02 / 2004$ & 3 & 7.47 & 8 & 0.96 \\
\hline Hamburg & $03 / 2004$ & $02 / 2008$ & 2 & 10.53 & 13 & 1.00 \\
\hline Hamburg & $03 / 2008$ & $03 / 2011$ & 8 & 9.94 & 7 & 0.99 \\
\hline Hesse & $04 / 1999$ & $12 / 2002$ & 0 & 14.48 & 14 & 1.00 \\
\hline Hesse & $04 / 2003$ & $12 / 2007$ & 9 & 13.11 & 28 & 0.96 \\
\hline Lower Saxony & $03 / 2003$ & $01 / 2008$ & 14 & 12.50 & 4 & 1.00 \\
\hline Mecklenburg-Western Pomerania & $10 / 1990$ & $09 / 1994$ & -1 & 9.67 & 15 & 0.92 \\
\hline Mecklenburg-Western Pomerania & $10 / 1998$ & $06 / 2002$ & II & 7.43 & 19 & 0.93 \\
\hline Mecklenburg-Western Pomerania & $10 / 2002$ & $06 / 2006$ & 10 & 8.06 & 17 & 0.88 \\
\hline North Rhine-Westphalia & $06 / 2000$ & $04 / 2005$ & 3 & 9.10 & 14 & 1.00 \\
\hline North Rhine-Westphalia & $06 / 2005$ & $06 / 2010$ & 7 & 11.94 & 30 & 0.99 \\
\hline Rhineland-Palatinate & $05 / 2001$ & $02 / 2006$ & 6 & 10.35 & 8 & 1.00 \\
\hline Saarland & $09 / 1999$ & $07 / 2004$ & 0 & 12.42 & 4 & 0.99 \\
\hline Saarland & $09 / 2004$ & $01 / 2009$ & 1 & 11.94 & 2 & 1.00 \\
\hline Saxony & $10 / 1990$ & $06 / 1994$ & II & 12.18 & 57 & 0.89 \\
\hline Saxony & $10 / 1994$ & $06 / 1999$ & 16 & $11.6 \mid$ & 39 & 0.93 \\
\hline Saxony & $10 / 1999$ & $06 / 2004$ & 15 & 11.66 & 18 & 0.80 \\
\hline Saxony & $10 / 2004$ & $01 / 2009$ & 5 & II.77 & 35 & 0.99 \\
\hline Saxony-Anhalt & $07 / 1994$ & $03 / 1998$ & -9 & 8.94 & 67 & 0.91 \\
\hline Saxony-Anhalt & $05 / 1998$ & $03 / 2002$ & -12 & 8.68 & 44 & 0.94 \\
\hline Saxony-Anhalt & $05 / 2002$ & $02 / 2006$ & 7 & 13.44 & 17 & 0.99 \\
\hline Schleswig-Holstein & $04 / 1996$ & $01 / 2000$ & I & 9.18 & 7 & 1.00 \\
\hline Schleswig-Holstein & $03 / 2000$ & $01 / 2005$ & I & 9.11 & 10 & 1.00 \\
\hline Thuringia & $10 / 1990$ & $09 / 1994$ & 8 & $|1.8|$ & 175 & 0.92 \\
\hline Thuringia & $11 / 1994$ & $07 / 1999$ & 26 & 11.42 & 162 & 0.95 \\
\hline Thuringia & $10 / 1999$ & $06 / 2004$ & 4 & 11.89 & 164 & 0.96 \\
\hline Thuringia & $07 / 2004$ & $08 / 2009$ & 0 & 11.29 & 142 & 0.98 \\
\hline$\sum$ & \multicolumn{2}{|c|}{193.5 years } & & & 2402 & \\
\hline
\end{tabular}




\section{Acknowledgements}

An earlier version of this study was presented at the 'Parliaments in Changing Times' -Inaugural General Conference of the ECPR Standing Group on Parliaments in Dublin, 24-27 June 2012. I thank Marta Bozdemir, Tristan Klinglhöfer, Johannes Kuhn, Michael Schulze, Christin Skiera and Heiko Wenzel for research assistance and Stefanie Bailer, Sebastian Eppner, Johannes Freundenreich, Steffen Ganghof, Katja Heeß, Jochen Müller, Stefan Schukraft, Ulrich Sieberer and three anonymous reviewers for helpful comments and suggestions.

\section{Funding}

This research received no specific grant from any funding agency in the public, commercial or not-for-profit sectors.

\section{Notes}

1. Here I focus on quantitative studies analysing unity scores and only partly refer to survey-based studies (e.g. Andeweg and Thomassen, 2011).

2. In his study of party unity in 19 countries, Carey (2007: 98) notes that the only information that was collectable for every vote from all cases was date, threshold for approval, and how each member of the assembly voted.

3. These problems also apply to other measures derived from voting behavior, such as ideal points (see Bräuninger et al., 2013).

4. In the Swiss lower house, for example, final passage votes (with higher unity) are automatically published, whereas votes on other motions (with lower unity) are not. Hence, ignoring this peculiarity, i.e. the higher share of important measures in the roll-call sample, would lead us into overestimating party unity in Switzerland (Hug, 2010; Schwarz, 2009; Schwarz and Lindner, 2006).

5. Related to that, party compositions influence the preference distribution at voting situations. Proposals of right-wing (opposition) parties, for example, are due to their extreme positions more easily voted down by government parties than that of moderate (opposition) parties.

6. In addition, there are more subtle voting rules that affect party unity, such as the party vote system in New Zealand (Kam, 2009; Williams, 2012: 569).

7. Note that the share of important motions in the roll-call sample and the respective average level of voting unity are also more indirectly influenced by the procedural costs of recorded votes. Electronic voting machines and ballot card procedures significantly reduce the time needed for the conduct of RCVs. This often translates into an increase in the overall number of RCVs and the share of unimportant votes (Carey, 2009: chs 3 and 4; Stecker, 2010; Saalfeld, 1995a).

8. In prominent studies, Finland (Depauw and Martin, 2008: 105; Sieberer, 2006b: 161), Poland and the Czech Republic (Carey, 2007: 99) exhibit comparatively low party unity. This low average unity (and high standard deviation) should also be seen as a function of the extraordinary high number of recorded votes in these countries and not just as resulting from the suggested institutional effects such as (in Finland) decentralized candidate nomination (Depauw and Martin, 2008: 117; Pajala, 2010; Sieberer, 2006b: 169) and (in Poland) intra-party electoral competition (Carey, 2007: 101). With increasing numbers of roll calls we are likely to see more minor issues in the sample (Depauw and Martin, 2008: 104). Accordingly, average unity scores will simply fall because on average incentives for party unity also fall, while all other explanatory variables remain unchanged.

9. In a game-theoretic analysis, Carrubba et al. (2008) demonstrate that in interaction with the specific institutional rules and parliamentary contexts, one goal alone - to control and discipline backbenchers - biases the sample to varying degrees and in different directions.

10. Variation of selection bias over time within a country could reduce the correlation with specific institutional setups. Yet, direct control of selection bias offers more safety. Furthermore, owing to the demanding data collection crossnational studies usually use roll calls from a very short period of time (in Carey's sample 775 days on average).

11. Pajala's (2010) analysis of Finland is another example of such a compensation. Here MPs are allowed to support budgetary amendments that relate to their home district, which, however, are always voted down with the help of all other government MPs.

12. See appendix for description of the dataset. The different number of terms with which state parliaments are represented in the dataset is due to the differing availability of voting lists that are analysable with semi-automatic methods.

13. More precisely, this right is often referred to a party group or/ and a specific number/share of MPs that is equivalent to the minimal size of a party group. Because of a 5 percent threshold this amounts to at least 5 percent of all seats. The only exception is Schleswig-Holstein, where 20 percent of all MPs are necessary to request a recorded vote (see online appendix).

14. Note that it was not possible to clearly identify and exclude so-called free votes from the sample. However, these votes, where whips do not set a party line, occur very rarely and should not influence the results.

15. There are four instances of minority governments (two over parts of a term and two over a full term). The variable majority takes negative values in these cases. Note that it is reasonable to add the number of seats of a stable supporting party to that of the minority government (Bale and Bergman, 2006). This alternative measurement (for two terms in SaxonyAnhalt) does not change the results.

16. As a rule of thumb, fewer than 20 observations do not allow for substantive inferences (Snijders, 2003: 676)

17. Note that all substantive results remain stable under different robustness checks such as the inclusion of party dummies, a fractional-response specification and weighting of cases by overall parliamentary agreement (see online appendix).

18. The small explanatory power of the model has to be interpreted in light of the small variance and bounded nature of the dependent variable. Note that the model fit increases to around 18 percent if all party group scores with perfect unity are dropped. 


\section{References}

Ainsley C and Maxwell L (2012) What can we learn from roll call votes? Strategic Signaling Incentives and the Decision to call roll call votes. Working Paper, Emory University.

Andeweg RB and Thomassen J (2011) Pathways to party unity: Sanctions, loyalty, homogeneity and division of labour in the Dutch parliament. Party Politics 17: 655-672.

Bale T and Bergman T (2006) Captives no longer, but servants still? Contract Parliamentarism and the new minority governance in Sweden and New Zealand. Government and Opposition 41: 422-449.

Benedetto G and Hix S (2007) The Rejected, the Ejected, and the Dejected: Explaining Government Rebels in the 2001-2005 British House of Commons. Comparative Political Studies 40: 755-781.

Blumenau J (2012) Agenda Control and Party Cohesion in the European Parliament. Presented at the ECPR Joint Sessions Workshop and the EPSA General Conference, 2012.

Bowler S, Farrell DM and Katz RS. (1999) Party Cohesion, Party Discipline and Parliaments. In: Bowler S, Farrell DM and Katz RS (eds) Party Discipline and Parliamentary Government. Columbus: Ohio State University Press, 3-21.

Brambor T, Clark WR and Golder M (2006) Understanding interaction models: Improving empirical analyses. Political Analysis 14.

Braun D, Seher N, Tausendpfund M, et al. (2010) Einstellungen gegenüber Immigranten und die Zustimmung zur Europäischen Integration. Eine Mehrebenenanalyse. Arbeitspapiere des Mannheimer Zentrums für Europäische Sozialforschung.

Bräuninger T and Debus M (2012) Parteienwettbewerb in den deutschen Bundesländern. (unter Mitarbeit von Jochen Müller). Wiesbaden: VS Verlag für Sozialwissenschaften.

Bräuninger T, Müller J and Stecker C (2013) Selection bias in ideal point estimation. An analysis of the utility function of legislative voting depending on type and mover of a motion. Paper prepared for the 71st meeting of the Midwestern Political Science Association.

Carey JM (2007) Competing principals, political institutions, and party unity in legislative voting. American Journal of Political Science 51: 92-107.

Carey JM (2009) Legislative Voting and Accountability. Cambridge: Cambridge University Press.

Carrubba C, Gabel M and Hug S (2008) Legislative voting behavior, seen and unseen: A theory of roll-call vote selection. Legislative Studies Quarterly 33: 543-572.

Carrubba CJ, Gabel M, Murrah L, et al. (2006) Off the record: Unrecorded legislative votes, selection bias and roll-call vote analysis. British Journal of Political Science 36: 691-704.

Cheibub JA (2007) Presidentialism, Parliamentarism, and Democracy. New York: Cambridge University Press.

Coman EE (2012) Legislative behavior in Romania: The effect of the 2008 Romanian electoral reform. Legislative Studies Quarterly 37: 199-224.

Cox GW and McCubbins MD (1993) Legislative Leviathan. Party Government in the House. Berkeley, CA: University of California Press.
Cox GW and McCubbins MD (2005) Setting the Agenda. Responsible Party Government in the U.S. House of Representatives. Cambridge: Cambridge University Press.

Crespin MH, Rohde DW and Vander Wielen RJ (2011) Measuring variations in party unity voting: An assessment of agenda effects. Party Politics.

Crisp BF and Driscoll A (2012) The strategic use of legislative voting procedures. Legislative Studies Quarterly 37: 67-97.

Curini L and Zucchini F (2012) Government alternation and legislative party unity: The case of Italy, 1988-2008. West European Politics 35: 826-846.

Dalton RJ and Anderson C (2011) Citizens, Context, and Choice: How Context Shapes Citizens' Electoral Choices. Oxford and New York: Oxford University Press.

Davidson-Schmich LK (2006) Becoming Party politicians. Eastern German State Legislators in the Decade Following Democratization. Notre Dame, IN: University of Notre Dame Press.

De Georgi E and Marangoni F (2011) The Italian parliamentary opposition in the alternation era: How consensual, and why? Paper presented at the Italian Political Science Association Annual Meeting, Palermo, September 2011.

Delius M, Koß M and Stecker C (2013) Ich erkenne also Fraktionsdisziplin grundsätzlich auch an ... - Innerfraktioneller Dissens in der SPD-Fraktion der Großen Koalition 2005 2009. Zeitschrift für Parlamentsfragen 44: 546-566.

Depauw S and Martin S (2008) Legislative party discipline and cohesion in comparative perspective. In: Giannetti D and Benoit K (eds) Intra-Party Politics and Coalition Governments. Abingdon: Routledge, 103-120.

Desposato SW (2005) Correcting for small group inflation of roll-call cohesion scores. British Journal of Political Science 35: 731-744.

Dewan T and Spirling A (2011) Strategic opposition and government cohesion in Westminster democracies. American Political Science Review 105: 337-358.

Diermeier D and Feddersen TJ (1998) Cohesion in legislatures and the vote of confidence procedure. American Political Science Review 92: 627-640.

Green-Pedersen C (2010) Bringing parties into parliament: The development of parliamentary activities in Western Europe. Party Politics 16: 347-369.

Hazan RY (2006) Does cohesion equal discipline? Towards a conceptual delineation. In: Hazan RY (ed.) Cohesion and Discipline in Legislatures, 1-11. New York: Routledge.

Hix S, Noury A and Roland G (2005) Power to the parties: Cohesion and competition in the European Parliament. British Journal of Political Science 35: 209-234.

Hobolt S, Tilley J and Banducci S (2012) Clarity of responsibility: How government cohesion conditions performance voting. European Journal of Political Research 52: 164-187.

Hox JJ (2002) Multilevel Analysis. Techniques and Applications. New York: Psychology Press.

Høyland B (2010) Procedural and party effects in European Parliament roll-call votes. European Union Politics 11: 597-613. 
Hug S (2009) Understanding roll call vote requests and their consequences [Manuscript].

Hug S (2010) Selection effects in roll call votes. British Journal of Political Science 40: 225-235.

Jun U, Haas M and Niedermayer O (2008) Parteien und Parteiensysteme in den deutschen Ländern. Wiesbaden: VS Verlag für Sozialwissenschaften.

Kam C (2009) Party Discipline and Parliamentary Politics. Cambridge: Cambridge University Press.

Klingemann H-D (2006) Mapping policy preferences. II: Estimates for parties, electors, and governments in Eastern Europe, European Union, and OECD 1990-2003. Oxford and New York: Oxford University Press.

Krehbiel K (1999) Paradoxes of party in Congress. Legislative Studies Quarterly 24: 31-64.

Long JS and Freese J (2006) Regression Models for Categorical Dependent Variables using Stata. College Station: Stata Press.

Martin LW and Vanberg G (2004) Policing the bargain: Coalition government and parliamentary scrutiny. American Journal of Political Science 48: 13-27.

Mielke S and Reutter W (2004) Länderparlamentarismus in Deutschland - Eine Bestandsaufnahme. In: Mielke S and Reutter W (eds) Länderparlamentarismus in Deutschland Geschichte - Struktur - Funktionen, 19-52. Wiesbaden: VS Verlag für Sozialwissenschaften.

Müller J (2009) The impact of the socio-economic context on the Länder parties' policy positions. German Politics 18: 365384.

Müller WC and Strøm K (1999) Policy, Office, or Votes? How Political Parties in Western Europe Make Hard Decisions. Cambridge: Cambridge University Press.

Owens JE (2006) Explaining party cohesion and discipline in democratic legislatures: Purposiveness and contexts. In: Hazan RY (ed.) Cohesion and Discipline in Legislatures, 12-40. New York: Routledge.

Ozbudun E (1970) Party Cohesion in Western Democracies: A Causal Analysis. Beverly Hills, CA: Sage.

Pajala A (2010) Plenary votes and voting cohesion in Eduskunta: A descriptive analysis of the 1991-2006 parliamentary years. Acta Politica Aboensia.

Pappi FU and Seher NM (2009) Party election programmes, signalling policies and salience of specific policy domains: The German parties from 1990 to 2005. German Politics 18: 403-425.

Patzelt WJ (1997) Ostdeutsche Parlamentarier in ihrer ersten Wahlperiode: Wandel und Angleichung. Historical Social Research 22: 160-180.

Patzelt WJ (2006) Party cohesion and party discipline in German parliaments. In: Hazan RY (ed.) Cohesion and Discipline in Legislatures, 102-115. New York: Routledge.

Rice SA (1928) Quantitative Methods in Politics, New York: Russell \& Russell.
Saalfeld T (1995a) On dogs and whips: Recorded votes. In: Döring H (ed.) Parliaments and Majority Rule in Western Europe, 528-565. Frankfurt/M: Campus.

Saalfeld T (1995b) Parteisoldaten und Rebellen. Eine Untersuchung zur Geschlossenheit der Fraktionen im Deutschen Bundestag (1949-1990). Opladen: Leske + Budrich.

Schwarz D (2009) Zwischen Fraktionszwang und freiem Mandat. Eine Untersuchung des fraktionsabweichenden Stimmverhaltens im schweizerischen Nationalrat zwischen 1996 und 2005. Norderstedt.

Schwarz D and Lindner W (2006) Mehrheits- und Koalitionsbildung im schweizerischen Nationalrat 1996-2005. Studie im Auftrag der Parlamentsdienste der schweizerischen Bundesversammlung.

Sieberer U (2006a) Agenda setting in the German Bundestag: A weak government in a consensus democracy. German Politics 15: 49-72.

Sieberer U (2006b) Party unity in parliamentary democracies: A comparative analysis. Journal of Legislative Studies 12: 150-178.

Snijders TA (2003) Multilevel analysis. In: Lewis-Beck MS, Bryman AE and Liao TF (eds.) The Sage Encyclopedia of Social Science Research Methods, 673-677. Thousand Oaks, CA: Sage.

Snyder R (2001) Scaling down: The subnational comparative method. Studies in Comparative International Development 36: 93-110.

Stecker C (2009) Setting the Roll Call Agenda. Paper prepared for the ECPR General Conference in Potsdam.

Stecker C (2010) Causes of roll call vote supply. Evidence from the German Länder. Journal of Legislative Studies 16: 438-459.

Thiem J (2006) Explaining Roll Call Vote Request in the European Parliament. MZES Arbeitspapiere / Working Papers 90.

Thiem J (2009) Nationale Parteien im Europäischen ParlamentDelegation, Kontrolle und politischer Einfluss. Wiesbaden: VS Verlag für Sozialwissenschaften.

Williams BD (2012) Institutional change and legislative vote consensus in New Zealand. Legislative Studies Quarterly 37: 559-574.

Yoder JA (1999) From East Germans to Germans?: The New Postcommunist Elites. Durham, NC: Duke University Press.

Zubek R (2011) Negative agenda control and executive-legislative relations in east central Europe, 1997-2008. Journal of Legislative Studies 17: 172-192.

\section{Author biography}

Christian Stecker is a Researcher and Lecturer at the Geschwister-Scholl Department of Political Science at the Ludwig-Maximilians-University of Munich. He has published articles on intra-party politics and legislative voting in the Journal of Legislative Studies, the Journal of European Public Policy and German Politics. 